\title{
Pääkirjoitus
}

\section{Kaiken maailman yrittäjäsubjekteja}

\author{
Heidi Henriikka Mäkelä \& Antti Lindfors
}

$\mathrm{V}$

äitöskirjatutkijan tai jo väitelleen humanistitieteilijän asema ei liene koskaan ollut erityisen kadehdittava ainakaan työn epävarmuuden tai palkan näkökulmasta. Viimeisen parinkymmenen vuoden aikana näitä työnkuvia koskevat muutokset ovat kuitenkin olleet nopeampia ja jossain määrin kivuliaampia kuin aiemmin, sillä tutkijoiden työ-ja toimintaympäristöä on nopealla aikataululla uudelleenorganisoitu huippu-, kilpailu- ja säätiöyliopiston tapaisin ideaalirakennelmin ja diskursiivisin kehystyksin (esim. Koskiaho 2021; Kuusela et al. 2021; Rinne et al. 2015). Nämä korkeakoulupolitiikan murrokset ja tutkijantyön uudet kontekstualisoinnit ovat tarkoittaneet sitä, että tutkijan on enenevissä määrin hallinnoitava omaa identiteettiään ja työnkuvaansa yrittäjyyden ja itsensä brändäämisen termein sekä mukauduttava esimerkiksi julkaisemisessa uudenlaisiin yhdenmukaisuuden vaatimuksiin (Koskiaho 2021, 48). Puhutaan uusliberaalista toimijuudesta (Gershon 2011) tai kilpailullisesta yrittäjäsubjektista, joka kykenee helpommin neuvottelemaan "portinvartijoiden ja päätöksentekijöiden kanssa kuin vanhan akateemisen kulttuurin edustajat" (Koskiaho 2021, 51).

Uudet vaatimukset alkavat näkyä paitsi tutkijan toiminnassa ja itseidentiteetissä, myös konkreettisesti hänen ruumiissaan. Englanninkielisiä, viittauksiin houkuttelevia, vertaisarvioituja artikkeleita on tuotettava mahdollisimman paljon, Twitter piipittää, JuFo-luokitukset kuumottavat niskassa. Samaan aikaan useat tutkijat voivat huonosti, kärsivät (mielen)terveysongelmista ja harkitsevat vakavasti alanvaihtoa.

Työn ja työuupumuksen historian tutkija Mona Mannevuo totesi Kulttuurintutkimuksen päivillä pidetyssä paneelikeskustelussa (9.12.2021), että uusliberaaliin akateemiseen työhön kohdistuvaa kritiikkiä on helppo heittää ilmoille. Samalla uusliberaali on valuva ja kritiikkiä pakeneva käsite, joka on "kaikkialla ja ei missään". Mannevuon huomio on nähtävissä esimerkiksi ihmis- ja yhteiskuntatieteellisen julkaisemisen ja uuden korkeakoulupolitiikan kehämäisessä suhteessa. Nykyisen akateemisen työn raadollisesta luonteesta on kirjoitettu valtavasti kriittiseen sävyyn, mutta samalla kyseiset kirjoitukset satavat tutkijoiden julkaisuluetteloiden ja yliopistoiden pisteytysjärjestelmien laareihin ylläpitäen omaa kritiikin kohdettaan (Koskiaho 2021, 49).

Julkaisuilla, teksteillä ja puheella on toisin sanoen performatiivista ja itseään uusintavaa voimaa, mutta vain oikeassa kontekstissa ja tätä voimaa tukevissa rakenteissa. Kiinnostavaa onkin tarkkailla, millaisia taktisia ja strategisia ohjeita tämän performatiivisuuden haltuunottoon annetaan. Esimerkiksi Mannevuo varoittaa ahdistuspuheen myös synnyttävän 
ahdistuspuhetta ja neuvoo kääntämään tunnepuheen asemesta katsetta "rakenteisiin". Toisenlaista, positiivisen performatiivisuuden voimaan toiveikkaasti luottavaa yksilölähtöistä taktiikkaa edustaa Väitöksen jälkeen: opas akateemiselle uralle -teoksessa annettu ohje, jossa nuorta tutkijaa vinkataan laatimaan itselleen toimintaa motivoiva, seinätauluksi ripustettava "akateeminen missiolause" (Isosävi \& Lindholm 2021, 28-31; vrt. Ahmed 2010).

Vastaava rakenteellinen ongelma tietysti palautuu nykyistä akateemista julkaisumaailmaa ylläpitävään keskeiseen pyramidihuijaukseen, jossa kansainväliset suuret kustantajat käärivät tutkijoiden työstä hyvät rahat myymällä saman työn artikkelien muodossa takaisin yliopisto- ja tutkijayhteisölle. Tästä liiketoiminnasta nettoavat eivät maksa itse tuotteesta mitään - eivät tutkijoille eivätkä esimerkiksi artikkelien arvioijille - vaan huvin kustantavat pääasiassa julkiset tahot ja säätiöt tutkimusrahoituksen muodossa. Samalla suomenkielisten, kengännauhabudjetilla toimivien tieteellisten julkaisujen on yhä vaikeampaa saada rahoitusta - eikä Elore ole tästä poikkeus - vaikka ne tekevät juuri sitä, mitä tiedejulkaisemiselta toivotaan: julkaisevat huolellisesti toimitettua, parin klikkauksen päässä olevaa open access -tutkimusta.

Yrittäjäsubjektia rakennetaan nykyään jo tutkijanuran ensiportailta alkaen, esimerkiksi tutkijakoulujen puitteissa. Toinen tämän pääkirjoituksen kirjoittajista piti tänä syksynä Helsingin yliopiston jatko-opiskelijoille suunnattua Writing Your Journal Article in Twelve Weeks -kurssia, joka pohjautuu samannimiseen myyntimenestysoppaaseen (Belcher 2019). Kurssilla on tarkoitus tuottaa 12 viikossa mahdollisimman hyvin kansainvälisessä julkaisuprosessissa pärjääviä, argumenttivetoisia ja otsikoiltaan mahdollisimman klikattavia artikkeleita. Opiskelijat kurssilla olivat ihania, viisaita ja hyviä keskustelijoita, ja artikkeleistakin tuli hienoja. Samaan aikaan toistuvia keskustelunaiheita kurssilla olivat paine, ahdistus, kirjoittamisen vaikeus, perhe-elämän ja työn yhdistämisen ongelmat ja väsymys - ihanteellinen yrittäjäsubjekti kohtasi ahdistuspuheen.

Pitäisikö siis rakenteiden korjaamiseksi lopettaa Writing Your Journal Article -kurssin tarjoaminen? Ehkäpä ei. Mutta voisiko tutkijakoulu joskus järjestää myös Kirjoita tosi syvällinen ja ihanan hidas artikkeli taikka muu teksti -kurssin, mieluiten suomeksi, ruotsiksi, saameksi tai vaikkapa karjalan kielellä?

Eloressa on onneksi mahdollista julkaista pitkään kypsyneitä tutkimuksen hedelmiä. Tämän numeron aloittaa Elli-Mari Aholan kirjallisuustieteestä ammentava artikkeli Kalevalaa hyödyntävistä muunnelmaromaaneista, joka syventyy eepoksen syntyhistorian uudelleenesittämisiin uusissa suomenkielisissä romaaneissa. Anssi Neuvosen ja kumppaneiden artikkeli karjalaisista muistin paikoista Helsingissä vaeltaa tarkkanäköisesti Karjalaa muistavissa helsinkiläisissä paikoissa, joissa limittyvät Helsingin arkkitehtuuri ja sen aineellisuus sekä muisteltu Karjala ja historiakulttuuri. Sonja Hagelstamin tekstissä analysoidaan YK-rauhanturvaajien valokuva-albumeita ja suunnataan katse kohti valokuvien esittämää kehollis-diskursiivista prosessia, jossa "kalkkilaiva"-valkoisesta aloittelevasta rauhanturvaajasta tulee ruskettunut "taistelija". Meri Kytö tarkastelee kauden mukaisessa artikkelissaan jouluisaa taustamusiikkia ja sen kokemista kaupunkitilassa, sekä ehdottaa jouluisalla musiikilla kaupungin koristelua erityiseksi kalendaarisesti ajoitetuksi taustamusiikkikäytännökseen. Kaarina Koski ja Pasi Enges erittelevät numeron päätösartikkelissa metsänpeiton eli epätavallisen eksymisen 
erilaisia tulkintamalleja ja sen selitysten variaatiota ja muutosta kansanomaisissa ja tieteellisissä diskursseissa. Monipuolisen artikkelikattauksen lisäksi numero sisältää tuttuun tapaan liudan ajankohtais- ja kirja-arviotekstejä.

Tämän kirjoituksen myötä myös väistyvä päätoimittaja Heidi Henriikka Mäkelä kiittää kaikkia asianosaisia hauskoista toimitushetkistä. Ensi vuonna Mäkelän tilalla Antti Lindforsin päätoimittajakumppanina jatkaa FT Anna Kinnunen Itä-Suomen yliopistosta. Rauhaa, kiireettömyyttä ja kiivasta rakenteiden tarkkailua kaikille!

\section{Lähteet}

Ahmed, Sara. 2010. Promise of Happiness. Durham: Duke University Press.

Belcher, Wendy Laura. 2019. Writing Your Journal Article in Twelve Weeks. A Guide to Academic Publishing Success. Second edition. Chicago \& London: The University of Chicago Press.

Gershon, Ilana. 2011. "Neoliberal Agency." Current Anthropology 52 (4): 537-55.

Isosävi, Johanna \& Lindholm, Camilla 2021. Väitöksen jälkeen: Opas akateemiselle uralle. Helsinki: Art House.

Koskiaho, Briitta. 2021. Yliopistoinstituution myllerrys ja uusliberalismi - esimerkkeinä Britannian yliopistot. Tieteessä tapahtuu 4: 46-51.

Kuusela, Hanna, Veera Kaleva, Tuukka Tomperi, Mikko Poutanen ja Tuomas Tervasmäki. 2021. Korkeakoulupolitiikan muuttuvat valtasuhteet Suomessa. Säätiöyliopiston synty ja kamppailu yliopistodemokratiasta. Politiikka 63 (2): 158-187.

Rinne, Risto, Arto Jauhiainen ja Raakel Plamper. 2015. Suomalaisen yliopiston itseymmärrys, itsepuolustus ja haasteet 1920-luvulta 2010-luvulle rehtoreiden puheissa. Kasvatus \& Aika 9 (3): 172-243. 